INTERNATIONAL JOURNAL OF MULTIDISCIPLINARY RESEARCh AND ANALysis

ISSN[Online] : 2643-9875 || ISSN[Print] : 2643-9840

Volume 3 Issue 09 September 2020

DOI: 10.47191/ijmra/v3-i9-05, Impact Factor : 5.522

Page No : $99-101$

\title{
Innovative Processes in the Field of Logistics of Uzbekistan
}

\author{
${ }^{1}$ Ya.K. Karrieva, ${ }^{2}$ Sh.A. Masharipova, ${ }^{3}$ B.K. Karrieva, ${ }^{4}$ Sh.S. Karrieva, ${ }^{5}$ F.A. Ibragimov \\ ${ }^{1}$ Doctor of Economic Sciences, Professor, Tashkent State Economic University \\ ${ }^{2} \mathrm{PhD}$, University Bucheon \\ ${ }^{3}$ Senior Lecturer, Tashkent State Technical University \\ ${ }^{4}$ Assistant Lecturer, Tashkent State University of Economics \\ ${ }^{5}$ Researcher, Tashkent State University of Economics
}

\begin{abstract}
This article discusses the innovative processes in the field of logistics in Uzbekistan. In the Action Strategy for the Development of the Republic of Uzbekistan in 2017-2021, the logistics sector received the status of a strategic sector of the national economy and a transition to a new qualitative stage of development began.

Correct construction and operation of logistics systems in the supply chain based on the introduction of innovation and technology, international standards for the functioning of integrated logistics is the key to successful activities in world markets and the integration of Uzbekistan into the modern structure of international economic relations. The transition to the concept of freight management logistics can significantly increase the efficiency and quality of transport services for consumers of transport services. The concept of innovative logistics management encourages an integrated, approach to transport process management in foreign economic operations.
\end{abstract}

\section{KEYWORDS}

Logistics, innovative technologies, globalization and internationalization, transport logistics.

\section{INTRODUCTION}

Therefore, the use of innovative technologies in the field of logistics and transport is considered to be very important today. Innovation is not any innovation or novelty, but an innovation that significantly increases the efficiency of an existing system.

Technological innovation is the acquisition of a new or efficient production of an existing product, product and technique, new or improved technological process [3].

The procedures for reforming railway transport, providing for the application of fundamentally new approaches to corporate based on the innovative principle of using resources, are an important part of the development of the transport system.

The priority of this task is to intensify innovative activities in railway transport, taking into account the network characteristics, regional capabilities and resources of railway transport. In a market economy, innovation becomes a unique asset of the enterprise that requires a special approach. Conditions must be created for the normal life cycle of the innovation process in transport [5].

This requires an objective theoretical analysis of the essence and trends in the development of innovative activities, clarification of contradictions that negatively affect economic results and the speed of innovative transformations of railways, as well as a detailed assessment of the effectiveness of the innovation process as an activity aimed at achieving the strategic goals of the company [2].

\section{THE MAIN FINDINGS AND RESULTS}

The economy of the Republic of Uzbekistan is going through a difficult period, especially now in the context of a pandemic, and requires a way out of the current economic situation. One of the ways, as world experience shows, is to build innovative logistics, logistics systems and methods in logistics management. According to many scientists in the field of economics, the logistics system is ultimately considered a complex economic system, and the most important part of logistics activities is innovative logistics. Often, innovative logistics is one of the concepts of integration, globalization and internationalization. Innovative logistics goes the way of improving the level of logistics process management in connection with 
Innovative Processes in the Field of Logistics of Uzbekistan

the use of various innovations aimed at improving the quality of customer service, increasing the efficiency of logistics processes and reducing various costs (Figure 1 ).

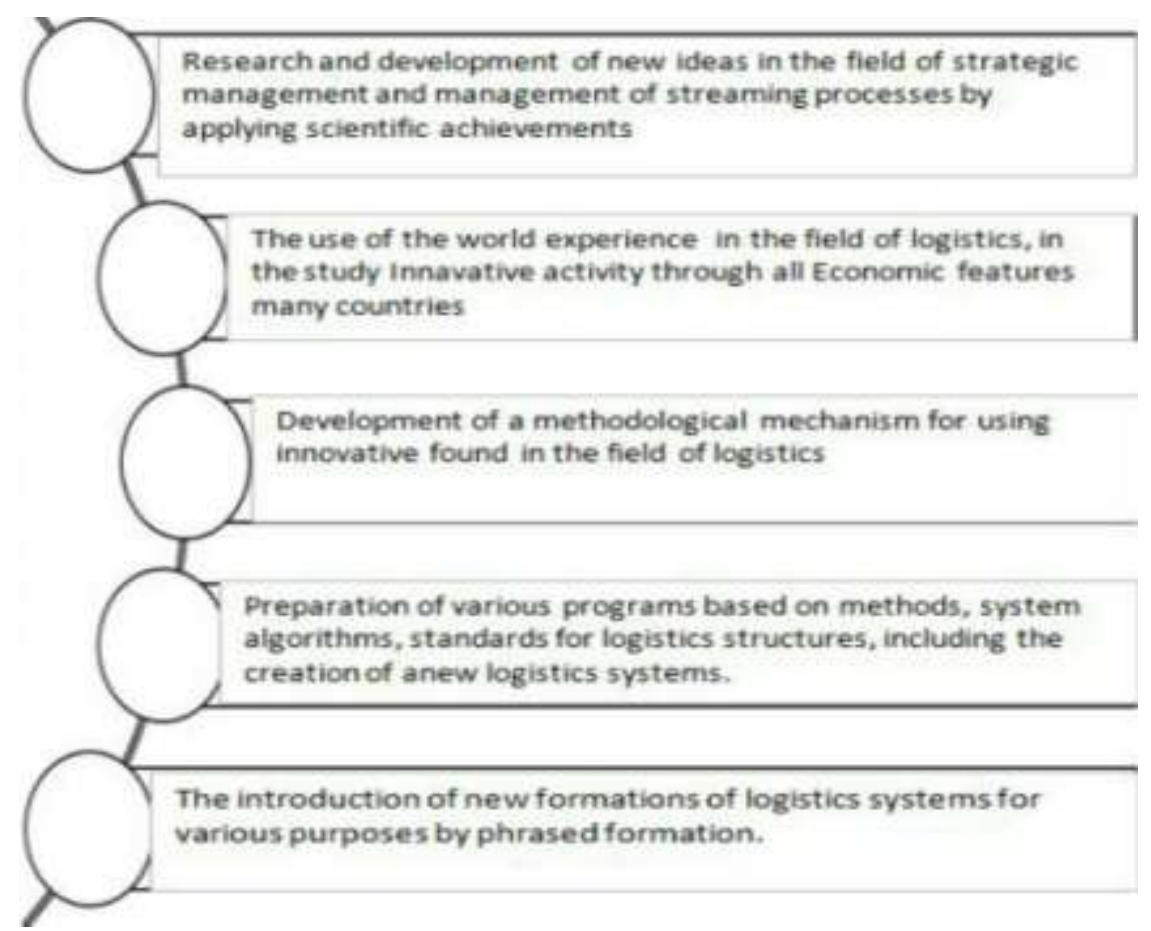

Figure 1: Areas of innovative logistics and their objectives[1]

Innovative logistics systems are linked and directly involved in the organizational system of commodity circulation, which is a chain of logistics operations and system-wide innovations. Drawing a conclusion from the above, we propose to consider the classification of logistics innovations (Table 1), in which it is possible to highlight the main directions of innovative logistics systems, as well as to identify the main objects of logistics activities [4].

Table 1: Classification of logistics innovations[2]

\begin{tabular}{|c|c|c|}
\hline № & $\begin{array}{l}\text { Classification } \\
\text { attribute }\end{array}$ & Types of logistics innovations \\
\hline 1 & Logistics areas & $\begin{array}{l}\text { - procurement activities } \\
\text { - storage facilities } \\
\text { - transport facilities } \\
\text {-Allocation of resources in production } \\
\text { - production processes } \\
\text { - Inventory Management } \\
\text { - sales activities }\end{array}$ \\
\hline 2 & Group of goods movement & $\begin{array}{l}\text { - functional logistics chains } \\
\text { - micrologistic chains } \\
\text { - macrologistic chains }\end{array}$ \\
\hline 3 & Scale of application & $\begin{array}{l}\text { - local industry } \\
\text { - intersectoral } \\
\text { - system-wide }\end{array}$ \\
\hline 4 & Usage level & $\begin{array}{l}\text { - operating } \\
\text { - procedural } \\
\text { - functional }\end{array}$ \\
\hline 5 & Business process type & $\begin{array}{l}\text { - technological } \\
\text { - organizational } \\
\text { - managerial }\end{array}$ \\
\hline
\end{tabular}


One of the components of innovative logistics is strategic logistics, which is primarily a science involved in the formation of logistics capacity in logistics process management systems. We consider it important to note that the logistics of structures have many differences in many ways:

1) builds a process of critical review and removal of specific constraints that put pressure on the organization;

2) All transformations of innovative logistics apply to the entire management system;

3) In the logistic process, all new divisions of the company pass into the degree of derivatives.

The process of formation and functioning of market structures is associated with the choice of strategies. Market structures create a system for managing streaming processes in a mutual partnership. In the logistics process, a specific logistic potential of structures in various forms of ownership is formed, which contributes to the successful solution of logistics problems. We consider it expedient to assess the current state of logistics innovations and the development of logistics in general in the economy of the Republic of Uzbekistan. In our country, the development of logistics is not proceeding at such a fast pace, as in the example, in the USA or in the West. And Western countries at that time directed all their efforts to modernize transport logistics, which, according to many foreign experts, turned out to be more effective, since in reducing the cost of logistics services, the main thing is the minimum storage time of products in warehouses and the process of loading and unloading [5].

\section{CONCLUSION}

In Uzbekistan, there is a need to develop logistic methods. The experience of other countries shows that the development of any innovations is primarily associated with a number of conditions, for example, with the level of technology development, with a good state of relations in the market and a favorable environment in the political environment.

In conclusion, it can be noted that the development of logistics in Uzbekistan has the following difficulties:

1) Instability in the economy;

2) The lag of our economy from the level of the world economy;

3) Transport infrastructure does not fully meet international requirements;

4) Insufficient level of development of the production and technological base;

5) The complexity of the development of industry in certain industries (production of containers, packaging);

6) Staffing problems in the field of logistics, etc.

\section{REFERENCES}

1) Karrieva Y.K. Strategy of functioning of logistics companies in Uzbekistan. International journal SCOPUS of "Innovation and Technology" USA. Syuracuse. 2019, July.

2) Trifilova A.A. Evaluation of the effectiveness of innovative development of the enterprise.Moscow: Finance and statistics. 2017. -p. 304.

3) Fedotenkov D.G. Innovative logistics as one of the keys in the development of the economy // Young Scientist. 2016. No. 4. - pp. 623-627.

4) Palnikova E.N., Patrakova V.L. Innovations in logistics systems. Moscow: 2018. -p. 1.

5) Kiseleva V.V., Kolosnitsyn M.G. State regulation of the innovation sphere. Moscow: 2016.

6) Dorofeev A.N.Trends in the development of transport logistics // Logistics. 2017. No. 2 (21). 